\title{
Code Switching and Representation of Elite Character in Social Media
}

\author{
Andri Fatihatal Putra* \\ Postgraduate English Department \\ Universitas Mataram \\ Mataram Indonesia \\ andrifatihatalputra@gmail.com
}

\author{
Lalu Muhaimi \\ Postgraduate English Department \\ Universitas Mataram \\ Mataram Indonesia
}

\author{
Sudirman Willian \\ Postgraduate English Department \\ Universitas Mataram \\ Mataram Indonesia
}

\begin{abstract}
This paper discusses about type of code switching, the function of code switching, and the use of code switching to represent Elites' character in Social Media. The study is qualitative method. The sources of the data were taken from any social media of Elite and collected by using observation and documentation. Then those data were analyzed through some stages, namely transcribing, classifying, analyzing, and interpreting. The study found that there are: (a) three types of code switching used by Elites, (b) five functions of code switching which used by Elites, and (c) some socio-pragmatic rationales why Elites use code switching to represent their character on Social Media.
\end{abstract}

Keywords - code switching, social media, elite figures

\section{INTRODUCTION}

In our social life, we are connected and interacted with so many people with different background. These differences lead to a classification of people, whether it is from their background knowledge, economic capability, or the class of caste, upper or lower. This phenomena also make people compete each other and try to represent their existences, especially it usually occurs when they using a social media.

There are a lot of people that can be consider as an Elite figures, such as resident, politician, King/queen, businessman or businesswoman, an actor/actress, famous preacher/priest, musician, etc.

Social class is also one and the oldest inequality in our society. People are very aware of their social class and need a confession from others to hold a high roles and responsibility from their society. People with high level or Elite figures tend to wear different clothes, behaved in a different way, even they will make a different varieties of language to distinguish from one to another

Besides, a lot of people especially Elite figures often use code switching for various reasons. The reasons are because they want to show the class group which they are belong and to attract attention. The term code switching has already use over a lot of linguistics fields. Multi language speakers have experienced an interest of bilingual or multilingual speech, and in particular, in code switching. Therefore, code switching became an interesting research, especially in analyzing how speakers use it for many purposes. Code switching refers to the notion of how Bilingual or Multilingual speakers change from one language to another language, whether it is in the spoken or written form.
Code switching is defined in various ways by numerous researchers. In general, it is the most common, unremarkable and distinctive feature of bilingual behavior [1]. One of the most used definitions was formulated by Gumperz, a pioneer in the field, who saw code-switching as the juxtaposition within the same speech exchange of passages of speech belonging to two different grammatical systems or subsystems [2]

Trudgill defines that code switching is the process whereby bilingual speakers switch back and forth between one language or dialect and another with the same conversation [3]. Myers et al., code switching is the term used to identify alternations of linguistics varieties within the same conversation [4]. There are various reasons why people often use code switching in communicate with another people, such as to emphasize the point of utterance, lack of vocabulary, habitual experience, mood of speakers, pragmatic reasons, to show identity or class of group, to attracts and find some attentions, etc.

Code switching also related with Bilingualism. Bilingualism is the phenomenon of speaking and understanding two or more languages. The term can refer to Individuals as well as the entire society. According to Wardhaugh, multilingualism involving balanced, native-like command of all the languages in the repertoire is rather uncommon [5].

Matsumoto et al., proposed that Many bilinguals are more proficient or fluent in one language or the other, different between languages may actually reflect differences in degree of proficiency rather than linguistic relativity [6]. Pavlenko elaborated the concept of thinking and speaking in people who speak more than one language. She explores the bilingual mind in order to reverse the mono-linguistic and thought into more bilingual point of view. Pavlenko also states that Bilingualism has been studied less extensively than mono-linguistic [7]. Theoretical models of bilingual development, competence, performance, and processing have not been sufficiently elaborate, and conceptual notions and definitions show a great deal of variability.

Over past decade, social media have connected deeply into the mechanics of every daily life of people, affecting the interaction of people whether it is in form of formal or informal. Nowadays, people cannot be separated from social 
media, indeed for Elite figures who have a big role and popularity among society.

People use social media sites such as Face book, Twitter, and My Space to create and sustain relationships with other [8]. These Social Media let those who use it to campaign, advertising, preaching, write about their daily life, or even want to interacted and show their existence to people. There are some reasons why people use social media. The main four reasons found for social media use for emotional, cognitive, habitual, and social needs [9].

Other study found more specific about the themes among user of social media and why they use social media. These themes included social interaction, information seeking, pass time, entertainment, relaxation, communicatory utility, and convenience utility. Communicatory utility was used for those who used social media as a way to provide information to others, whether it was personal information or public information [10]

Boyd et al., also defined social network sites as public web-based services that allow users to develop a personal profile, identify other users with whom they have a connection, read and react to postings made by other users on the site, send and receive messages either privately or publicly [8]. Therefore, social media have a big role to make the interaction become easier and faster around every part of the world.

\section{METHOD}

This study is a qualitative one that does not need statistical package but the descriptive one. The descriptive explanation used to describe the result of the analysis. The research conducted in some stages, observing the Elite Figures on Social Media, it could be from YouTube, face book, Instagram, etc., $2 . \quad$ Recording the data which are taken from the sources, replaying the data to make sure everything uttered by the Elite figure can be transcribe completely, transcribing the recorded data into written form of data, analyze and interpret the data to answer research problems, and drawing the conclusion.

This research applied some methods to collect the data. There are through observation, recording, and transcribing the data. Observation (this method was conduct through observation), recording (while conducting the data, this technique is needed to make the data clear), transcribing the data (in this research, the data in the form of spoken was convert into a written form to make the data easier to analyze. After analyze the data, the data was given codes to make a classification and the data which is analyze is become easier), and data coding (in this research, the data were given some codes. The first datum is listed with number 1 , and the second is listed with number 2, and so on). The codes are explaining the list below.

\section{Stl: situational code switching}

Tg: tag code switching

Its: inter-sentential switching

Itr: intra-sentential switching

Other codes based on the function

Quot: quotation

\section{Ads: Addressee Spesification}

Ijc: injection

Rit: reiteration

Mq: message qualification

This is an example of how to read data coding: (1/tg/rit), it means that the first datum, types of tag code switching the function is reiteration.

\section{RESULT AND DISCUSSION}

Based on the data analysis, it can answer the problem which is mention in the previous section, the result is shown as the result of data analysis. The data was transcribed into written text to make it easier to analyze. It was performed by the former President of United States and two well-known artist, Boy William and Cinta Laura Kiehl. The following discussion explain about the types, the functions and what is reasons why those Elite perform code switching as the representation of their characters. There are 2 data belongs to conversational and speech in front of the audience. Those data are analyzed to answer the problem which is mentioned in the previous section.

\section{A. Types of Code Switching}

There are 3 types of code switching, that is Situational code switching, metaphorical code switching, and conversational code switching. But, in the data which has been analyzed occur only 2 types of code switching, they are situational and conversational code switching.

\section{1) Situational Code Switching}

Situational code switching is the tendency in a speech community to use different social situations, or to switch structures in order to change an established social setting and motivated by changes in factors external to the participant's motivation. There is only 1 data that can be categorized into this type of switching, as follows:

Cinta: Yes, dan bulan maret lalu, aku ke stockholm, Sweden recording 4 lagu. Dan, we do a lot of things coming up. We have (start yells and excited) owww, Can I show on your show guys?

Boy: Yes, please please.

Cinta:(start looking on the camera and promoted something about her single)

Kalo kalian ingin, mungkin masuk di video clip aku yang selanjutnyaa tajadi dancer aku, aku maunga dain video challenge. Jadi kalian post aja video kalian nge dance pake lagu vida, post di instagram hashtagvida challenge.

This conversation is belong to situational code switching, but just one data that can be consider as situational code:

Cinta:(start looking on the camera and promoted something about her single) 
Kalo kalian ingin, mungkin masuk di video clip aku yang selanjutnya atau jadi dancer aku, aku maungadain video challenge.Jadi kalian post aja video kalian nge dance pake lagu vida, post di instagram hashtagvida challenge.

When she looked on the camera and promoted for her new single of song, she immediately changes her language from English language into Indonesian language in order to make the participants or the audience clearly understand the message of what she conveys.

\section{2) Conversational code switching}

Second type of code switching occurs on both of the data. Conversational code switching divided into3 types, they are: tag-switching, inter-sentential switching, and intra-sententialswitching.

\section{a) Tag-switching}

This type add a tag of one particular language into an utterance of another language. In Obama's speech, for instance:

\section{-(01/tg/rit) “Terimakasih, Thank you so much.”}

It can be seen that the tag of the word "terimakasih" comes from indonesia language. heincludes one word in indonesian language and speaks with mostly in english language. we can also look for another example from Cinta Laura and Boy William conversation.

Cinta:We haven't hangout in the longest time. And I really miss you.

Boy: By the way, sebelumnya. I want to say congratulation kamujauhjauhbalikdariAmerikakeindonesiabikin single

It shows that Boy William insert or tag the words" sebelumnya" which is come from Indonesia utterance.

\section{b) Intra-sentential switching}

Intrasentential switching refers to a type which is the alternation in a single discourse between two languages, where the switching occurs within a sentence. The example of this type is below:

Becaks(6/itr/quot) and bemos(7/itr/quot) that's how you got around and they are outnumber of those days.

In this data, the speaker inserts the word from Indonesian language inside the sentence, Becaks and Bemos.

c) Inter-sentential switching

Inter-sentential refers to alternation in a single discourse between two languages, where the switching occurs after a sentencein the first languagecompleted and the next sentence starts with a new language. The example of this type is below:

Cinta: Yes, and guess what guys, you, Boy William, dia yang nyuruhakubikin single(11/itr) pertama and I showed you every first of my single

In the data above, the switches occur at a clause or sentence boundary, where on the one hand is Indonesian language and English language on the other.

\section{B. The function of code switching}

\section{1) Quotation}

The function of code switching as quotation is used to quote term or a familiar saying in other language.

"pulangkampungnih" (4/quot), I am so glad that I back to Indonesia and Michelle was able to join me

"pulangkampungnih"is the terms of Indonesian language which the speaker use to speak infront of the audience. He quotes the term of Indonesian language and speak in English.

\section{2) Injection}

Code switching can be as a sentence filler. It means that it might be some points and monolingual utterance without harming the syntactic rules of sentence or utterance.

\section{3) Reiteration}

It often happens when someone say or convey a message and repeats in other code either literary or in somewhat modified form.

Terimakasih (1/ijc), Thank you so much. (2/tg/rit)

Assalamualaikumdansalamsejahtera (3/rit)

The data above show that repetition of one language to another language occur. When the speaker says terimakasih, which is the word of Indonesia Language and immediately followed by Thank you so much in English language. The second example is also the same, but Assalamualaikum is froarabic language and often used by Indonesian people to greet someone.

4) Message qualification

Message qualification is used to qualify the message or to show the distinction between parts of the discourse.

Cinta: Yes (20/ijc), danbulanmaretlalu, akukestockholm, Sweden recording (21/itr) 4 lagu. Dan, we do a lot of things coming up. We have (start yells and excited) owww, Can I show on your show guys? (22/its)

Boy: Yes, please please. 
Cinta: (start looking on the camera and promoted something about her single)

Kalo kalian ingin, mungkinmasuk di video clip (23/itr) aku yang selanjutnyaataujadi dancer (24/itr) $a k u$, akumaungadain video challenge.Jadi kalian post(25/tg/itr) aja video kalian nge dance (26/itr) pakelaguvida, post(27/tg) di instagramhashtag (28/itr)vida challenge.(29/stl/mq/Ads).

When cinta Laura speaks to Boy William, she switches the language into Indonesian language to qualify the message.

\section{The factors of code Switching}

Code Switching is usually related to the pragmatic or the situation which occur on the speech or conversation. There are many reasons why people do code switching. Below are the explanation of these factors:

1) The participant

The first factor that make code switching occur is the participant of the speech or conversation. For example is shown in the example below:

\section{Assalamualaikum dan salam sejahtera (3/rit).}

Thank you for this wonderful welcome.

At that particular situation, Barack Obama use the indonesian language utterance to greet people or the participants. He knows that is a good idea to greet participant in the native language of the participants and represent him as a friendly people and respect to the people in other country. It also occur when Cintalaura want to talk with the audience, she change the language from English into Indonesian Language to make the audience clearly understand what she said in Indonesia language . Look at the example below:

Cinta: Yes (20/ijc), dan bulan mare tlalu, aku ke stockholm, Sweden recording (21/itr) 4 lagu. Dan, we do a lot of things coming up. We have (start yells and excited) owww, Can I show on your show guys? (22/its)

Boy: Yes, please please.

Cinta: (start looking on the camera and promoted something about her single)

Kalo kalian ingin, mungkin masuk di video clip (23/itr) aku yang selanjutnya atau jadi dancer (24/itr) aku, aku maunga dain video challenge. Jadi kalian post(25/tg/itr) aja video kalian nge dance (26/itr) pakel agu vida.

\section{2) The change of the topic}

The change of the topic also motivated people to change or switch the language. It can be seen When Cinta Laura want to talk to promoted her single. In this case, she represent herself as the people of Indonesia that talking to another Indonesian people. So she switches the language from English into Indonesian language because of that. The example is below:

Cinta: Yes (20/ijc), dan bulan maret lalu, aku ke stockholm, Sweden recording (21/itr) 4 lagu. Dan, we do a lot of things coming up. We have (start yells and excited) owww, Can I show on your show guys? (22/its)

Boy: Yes, please .

Cinta: (start looking on the camera and promoted something about her single)

Kalo kalian ingin, mungkin masuk di video clip (23/itr) aku yang selanjutn ya atau jadi dancer (24/itr) aku, aku maunga dain video challenge. Jadi kalian post(25/tg/itr) aja video kalian nge dance (26/itr) pake lagu vida.

\section{3) Lack of Vocabulary}

When Obama speech Infront of people, He mention some words because lack of knowledge with that particular terms. He represent himself as the foreigner that does not know the term itself instead of just use the original term. The example is below:

Becaks(6/itr/quot) and bemos(7/itr/quot) that's how you got around and they are outnumber of those days

He does not know what is the terms of Becak and Bemo belong, instead of just saying the terms in the target language of the participants.

\section{4) To emphasize the particular terms.}

The last factor which is occur in the data is the emphasize of particular terms in the target language. He emphasizes a particular term to give the stress to the words. When Obama Greet the audience, first he says Terimakasih and immediately followed by Thank you so much that actually have the similar meaning. It represent that he really loves Indoenesia, so he uses Indonesian language a lot of his speech and followed by the applause of the audience.The example is below:

Terimakasih (1/ijc), Thank you so much. (2/tg/rit)

\section{CONCLUSION}

This research answered the research problems, but not all the questions because there is one type of code switching did not occur in the data which is metaphorical code switching. And it also occurs in the function in the function and the factor of code switching. 


\section{REFERENCES}

[1] W. Li and P. W. Martin, "Conflicts and tensions in classroom codeswitching [Special issue]," Int. J. Biling. Educ. Biling., vol. $13,2009$.

[2] J. J. Gumperz, Discourse strategies, vol. 1. Cambridge University Press, 1982.

[3] L. Bauer and P. Trudgill, Language myths. Penguin UK, 1998.

[4] C. Myers-Scotton, Social motivations for codeswitching: Evidence from Africa. Oxford University Press, 1995.

[5] R. Wardhaugh, An introduction to sociolinguistics, vol. 28. John Wiley \& Sons, 2011.

[6] L. Matsumoto, D. \& Juang, Culture and psychology(3rd Edition). London: Wadsworth/Thomson, 2003.

[7] A. Pavlenko, Emotions and multilingualism. Cambridge University Press, 2007.

[8] D. M. Boyd and N. B. Ellison, "Social network sites: Definition, history, and scholarship," J. Comput. Commun., vol. 13, no. 1, pp. 210-230, 2007.

[9] Z. Wang, J. M. Tchernev, and T. Solloway, "A dynamic longitudinal examination of social media use, needs, and gratifications among college students," Comput. Human Behav., vol. 28, no. 5, pp. 1829-1839, 2012.

[10] A. Whiting and D. Williams, "Why people use social media: a uses and gratifications approach," Qual. Mark. Res. An Int. J., 2013. 